\title{
Problems of Translating Definiteness and Indefiniteness from Russian Into English and Arabic
}

\section{Lubna M. Khoshaba}

Department of English, College of Education and Languages, Lebanese French University, Erbil, Kurdistan Region, Iraq lubna.markus@lfu.edu.krd

\section{Marharyta Alsultan}

Department of English, College of Education and Languages, Lebanese French University, Erbil, Kurdistan Region, Iraq marharyta alsultan@lfu.edu.krd

\section{ARTICLE INFO}

\section{Article History:}

Received: 28/3/2021

Accepted: $11 / 5 / 2021$

Published: Summer 2021

\section{Keywords:}

Definiteness, Indefiniteness, Russian, English, Arabic, zeroarticle languages, article languages, determiners.

Doi:

10.25212/Ifu.qzj.6.3.37

\begin{abstract}
This research paper is devoted to studying of the definiteness and indefiniteness phenomenon in three genetically and structurally unrelated languages, namely: Russian, English and Arabic. No doubt, definiteness and indefiniteness have been studied by different grammarians in different languages. It is well-known that a noun phrase may contain an element to show definiteness and indefiniteness. This element is represented differently according to the language used. It can be lexical such as "the" or "a, an" in English, while in Arabic, a prefix "al" which expresses definiteness and a prefix (-n) expresses indefiniteness. This study aims at: (1) translating the definiteness and indefiniteness phenomenon from Russian into English and Arabic to find out the areas of similarity and difference between the languages in question, (2) attempting to arriving at solutions for the problems of translating the articles in question from Russian into the languages under discussion in case of existing differences.

The present study hypothesizes that definiteness and indefiniteness in Russian, English and Arabic languages are language-universal, but in very few cases, are languagespecific, definite and indefinite articles exist in Russian and
\end{abstract}


English languages, whereas definite article exists, but the indefinite article is represented by (nunation) "التنوين" in Arabic.

\section{Introduction}

The phenomenon of definiteness/indefiniteness is a conceptual category that exists in any language. It serves to give a noun a shade of certainty/uncertainty using various linguistic (article, pronouns, word order, numbers, etc.) and non-linguistic (facial expressions, gestures) means.

The study of definiteness and indefiniteness, in both morphological and functionalsemantic aspects, involves a wide range of theoretical problems and is often considered based on the material of languages that have a constant, mandatory in use indicator - the article. A large number of studies have been devoted to the study and description of languages that possess articles. (N. Arutyunova, S. Bally, A. Bondarko, V. Vinogradov, V. Gak, G. Guillaume, S. Katsnelson, V. Kashkin, K. Krushelnitskaya, S. Krylov, I. Revzin and many others).

In recent decades, there have been many works related to analyzing the functionalsemantic field of the category of definiteness/indefiniteness in Russian. Basically, research is conducted in the field of identifying individual means of expressing the meanings of the category under consideration (T.M. Nikolaeva (1995), N.S.Pospelov (1970), O.N.Seliverstova (1987-1988), and others). Also relevant are the works in which attempts are made to systematically describe the functional-semantic field of the given phenomenon as a weakly centered and uniting phonetic, lexical, morphological and syntactic language means (V. Gladrov (1992), Ya. Ulyasheva (2005).

In modern linguistics, interest in the problems of text formation is growing, that is the actual division of sentences, the issue of actualizing the meaning of the components of an utterance, cognitive knowledge about the world of objects, persons, facts, etc. The relevance of the work is due to the recently increased interest in actualizing the name in speech, attempts to create a unified classification of languages by the ways 


\section{QALAAI ZANISTSCIENTIFIC JOURNAL \\ A Scientific Quarterly Refereed Journal Issued by Lebanese French University - Erbil, Kurdistan, Iraq \\ Vol. (6), No (3), Summer 2021 \\ ISSN 2518-6566 (Online) - ISSN 2518-6558 (Print)}

of expressing definiteness/indefiniteness. The analysis of the data on the problem allows us to assert that nowadays, the diachronic universality of the considered category in the language has not yet been studied. Basically, the means of expressing the category of definiteness/indefiniteness in individual languages and ways of conveying their meaning in article-free languages are considered.

The object of the research is the category of definiteness / indefiniteness

The subject of the work is the category of definiteness / indefiniteness in languages of different systems: Russian, English and Arabic.

Different scholars in different languages have studied definiteness and indefiniteness. This phenomenon has played an important role in grammar, philology, syntax etc. A noun phrase may contain an element to show definiteness and indefiniteness. This element is represented differently according to the language used. It can be lexical such as "the" or "a, an" in English, while in Arabic, a prefix "al" expresses definiteness and a prefix (-n) expresses indefiniteness. Using such elements influence the meaning of sentences. For example, using the definite article means that the speaker indicates a particular thing that he already knows about (Lyons, 1999:1-2).

The research aims at identifying and analyzing the means of expressing the category of definiteness/indefiniteness in the languages of different systems and in Russian as an article-free standard language and determining the typological trends in the formation of grammatical means of expressing the category of definiteness / indefiniteness.

\section{Category of Definiteness/Indefiniteness in Russian}

For a long time, it was believed that the category of definiteness/indefiniteness is not a characteristic of the Russian language, since it lacks a formal grammatical indicator of this category which is the article. Linguistic research on the disclosure of the content of definiteness/indefiniteness was carried out mainly in connection with the study of articles. 


\section{QALAAI ZANISTSCIENTIFIC JOURNAL \\ A Scientific Quarterly Refereed Journal Issued by Lebanese French University - Erbil, Kurdistan, Iraq \\ Vol. (6), No (3), Summer 2021 \\ ISSN 2518-6566 (Online) - ISSN 2518-6558 (Print)}

The category of definiteness/indefiniteness has recently been the subject of special research in those languages that do not have articles. There are a number of studies devoted to the methods of expressing definiteness/indefiniteness in Russian. The studies of E.M. Galkina-Fedoruk, N.S. Pospelova, D.I. Fursenko, T.A. Papenkova, A.V. Bondarko, Yu.A. Rylov, O.B. Akimov, E.M. Nikolaeva, Z.M. Ganeeva, M.V. Horn had proven the existence of the category of definiteness/indefiniteness in Russian wherein also a whole system of linguistic and non-linguistic (facial expressions, gesture) means for expressing it exists.

In any modern language, there is semantics of definiteness/indefiniteness, which is expressed by various means. The opposition of definite/indefinite of the referent in several languages is marked grammatically - with the help of a particular lexicogrammatical category of words - articles: definite and indefinite. In other languages, where this category is not grammatical, different categories of the language can serve as means of actualization of the corresponding nouns.

The existence of the category of definiteness/indefiniteness in the Russian language has been controversial in linguistics for many years. According to Reformatskiy, this category is "very essential for the grammar of the Romano-Germanic languages and is clearly expressed in these languages by the difference between the definite and indefinite articles, though it is absent in the Russian language, this does not mean that the Russians cannot have these meanings in their consciousness" (Reformatskiy, 1967).

\subsection{Means of Expressing Definiteness/Indefiniteness in Russian}

The function of determination in modern Russian is expressed by lexical, grammatical, morphological and syntactic means of actualization.

Lexical actualizers include demonstrative and indefinite pronouns, adverbs, possessive pronouns, combinations with particles, phrases with numerals, deicticity, anaphoricity, phrase units with the core of definiteness / indefiniteness, phraseological combinations. 


\section{QALAAI ZANISTSCIENTIFIC JOURNAL \\ A Scientific Quarterly Refereed Journal Issued by Lebanese French University - Erbil, Kurdistan, Iraq \\ Vol. (6), No (3), Summer 2021 \\ ISSN 2518-6566 (Online) - ISSN 2518-6558 (Print)}

Demonstrative and indefinite pronouns are the most prominent exponents of the category of definiteness / indefiniteness. "The demonstrative pronoun of the modern type is the greatest abstraction, but the abstraction is not empty, but the most valuable, genuine; like any true generalization, the modern pronoun contains all infinite variety separate and single" (Yakubinsiy, 1953). For instance:

E.g. Петя хочет жениться на какой-то студентке (неопределенное имя) (Pete wants to marry a student). Вот та книга (определенное имя) (Here is the book).

The lexical method is a combination of a noun with an indefinite or demonstrative pronoun: этот, тот, кое-кто, кто-то, кто-нибудь и т.д. (this, that, something, someone, etc.):

E.g. Все четыре центра лежат в одной плоскости (The four centres lie in a plane).

Kobozeva notes that "In the Russian language, the category of definiteness/indefiniteness is not grammatical, the pronouns can serve as actualizers of the corresponding reference statuses" (I. Kobozeva, 2004). It is worth noting that this method is also a characteristic of the English language.

For example, the indefinite article can be expressed in Russian by such words as “некоторый”, “один” ("some”, “one”):

E.g. У него не было ни единого шанса. (He did not have a chance).

As for grammatical means of actualization, they include the category of the type of the verb, the category of the number, modality:

Е.g. Вы уже переводили английские стихотворения? (значение неопределенности). Вы уже перевели английские стихотворения? (значение определенности). Have you already translated English poems? (value of uncertainty). Did you translate English poems? (meaning of certainty).

Definiteness/indefiniteness in Russian is partly related to the category of numbers: the use of plural forms as markers of indefiniteness. That is to say, the meaning of 


\section{QALAAI ZANISTSCIENTIFIC JOURNAL \\ A Scientific Quarterly Refereed Journal Issued by Lebanese French University - Erbil, Kurdistan, Iraq \\ Vol. (6), No (3), Summer 2021 \\ ISSN 2518-6566 (Online) - ISSN 2518-6558 (Print)}

indefiniteness appears in cases where the plural of a noun transmits a noun denoting a single unit. For instance:

Е.g. Осторожно! Здесь гвозди! (человек наткнулся в темноте на гвоздь) (Watch out! There are nails!)

У меня здесь есть друзья (хотя бы один) (I have friends here).

У меня здесь нет друзей (ни одного) (I have no friends here).

The syntactic method is determined by the position of words in the sentence.

Е.g. Было обнаружено, что лигнин сосны ладанной легче превратить в волокнистую массу, чем природный лигнин, благодаря эксперименту, который проводили правительственные ученые совместно с учеными различных институтов ( $\mathrm{A}$ recent collaboration between academic and government scientists has led to the characterization of a lobby pine lignin that is easier to pulp than normal lignin).

Книга лежит на полке and На полке лежит книга (The book is on the shelf).

The interchange of a theme (already known) and rhyme (new information) creates an actual division of the text. Since there is a fixed word order in a sentence in English, this way of expressing the category of definiteness/indefiniteness is not relevant. However, there is also the concept of inversion, which emphasizes that rhyme is the subject. In English, for instance, the indefinite article may indicate a rhyme in the sentence, thereby showing what word order is needed when translating. If the subject in the sentence is indefinite (or zero, in the case where the subject used in the plural), then in translation into Russian, it should begin with a predicate or with an adverbial modifier:

E.g. В реакции того же типа получен низкий выход диметилхлортиофосфата (In a related reaction a poor yield of dimethyl chlorophosphate was obtained).

The syntactic methods of transmitting indefiniteness in Russian include personalindefinite and impersonal sentences, the construction of "word ending with letter -o pronoun word". 


\section{QALAAI ZANISTSCIENTIFIC JOURNAL \\ A Scientific Quarterly Refereed Journal Issued by Lebanese French University - Erbil, Kurdistan, Iraq \\ Vol. (6), No (3), Summer 2021 \\ ISSN 2518-6566 (Online) - ISSN 2518-6558 (Print)}

So, for the expression of the indefiniteness, constructions of the tyре "неизвестно куда" ("God knows where") are used. The range of such words is limited, e.g. неведомо, невесть, непонятно, неясно, непостижимо, необъяснимо (no one knows, nobody knows, unknown, incomprehensible, inexplicable). The pronouns and adverbs adjacent to them are: кто, что, какой, чей (who, what, what, whose) in different case forms; когда, как, зачем, куда, откуда, почему, сколько, где (when, how, why, where, where, why, how much, where). For instance:

Е.g. Неизвестно куда, непонятно зачем, неведомо откуда, необъяснимо почему (It is not known where, it is not clear why, it is not known from where, inexplicably why).

Morphological actualizers include: the opposition of the Accusative and Genitive Cases, the full and short forms of adjectives, which serve as the article in RomanoGermanic languages.

Concerning the form of the genitive and accusative cases in the expression of definiteness/indefiniteness, it is believed that at the first mention, the noun, in the position of the direct complement, is in the Genitive case and thus conveys an indefinite meaning.

When the same object is mentioned repeatedly in the text, the noun appears already in Accusative Case. For instance:

E.g. Он написал отцу, что матери плохо живется, она болеет, и чтобы отец прислал ей денег на дорогу. Деньги она отдаст, вернувшись домой. (He wrote to his father that his mother is living not well, she is sick, and that he should send some money for the ticket. She will give back the money once she returns home).

Дай воды (воду); Он не ел груши (грушу);

Give water (Give the water); He did not eat pear (He didn't eat the pear).

To sum up, it must be admitted that to denote determination in modern linguistics, the terms of actualization, quantification, and reference are used. In English, the 


\section{QALAAI ZANISTSCIENTIFIC JOURNAL \\ A Scientific Quarterly Refereed Journal Issued by Lebanese French University - Erbil, Kurdistan, Iraq \\ Vol. (6), No (3), Summer 2021 \\ ISSN 2518-6566 (Online) - ISSN 2518-6558 (Print)}

indicator of determination is the category of articles. The article determines the uniqueness, exclusivity of the object in the described situation, or relates it to the class of similar phenomena or objects.

Thus, in modern Russian, the category of definiteness/indefiniteness is expressed by a whole complex of interacting means belonging to different language levels.

The category of definiteness/indefiniteness does not have a regular grammatical expression. Therefore, the considered tools are not universal, and they instead represent the features of the Russian language.

\section{Category of Definiteness/Indefiniteness in English}

Different ways in languages represent definiteness and indefiniteness of nouns. In English, the category of definiteness and indefiniteness is a semantic category that can be expressed by two articles: the definite article "the" and the indefinite article "a/an".

There are three types of articles in English:

1. Definite article "the" which is used before all types of nouns such as countable nous for example, the car, mass nouns like the tea.

2. Indefinite article "a" and "an" which are used before the countable nouns in singular form, for example a house, an apple, etc.

3. Zero article. It can be used with mass nouns and plural countable nouns for example, some milk, houses etc. (Al-Sualimaan \& Alsinjari, 2018:1078).

\section{Definiteness and Indefiniteness in Arabic}

Different languages have noun phrases that may refer to definiteness and indefiniteness. Morphologically, this phenomenon is expressed differently. In English for example, "the, a" are lexical items. However, in Arabic affixes such as, "al" "ال" which is a prefix and " $n$ " which is a suffix, are used to express this element. This suffix is used to express indefiniteness in Arabic and it is called "nunation". The definite article "al" is used in all contexts and cases without any changes. 


\section{QALAAI ZANISTSCIENTIFIC JOURNAL \\ A Scientific Quarterly Refereed Journal Issued by Lebanese French University - Erbil, Kurdistan, Iraq \\ Vol. (6), No (3), Summer 2021 \\ ISSN 2518-6566 (Online) - ISSN 2518-6558 (Print)}

Definiteness in Arabic is quite straightforward. The system of definiteness and indefiniteness is classified into definite or indefinite, nouns. As for pronouns, they are definite even if they are not marked by the definite article. Chafe (1976:30) states the following conditions for a noun phrase to be definite:

1. It is mentioned previously;

2. It is one of the unique entities;

3. Both speaker and listener must have shared knowledge about the concept in reality.

Pragmatically speaking, a definite noun expresses information presented by the speaker and delivered to the listener. However, the indefinite article is the one that does not meet any of the aforementioned conditions; therefore, it is unknown or refers to an unidentified object.

Definiteness and indefiniteness can also be explained in terms of reference, specific, generic and unique references. A noun can be definite when it is repeated in the same sentence and both the speaker and listener know the referent. In other words, the definite article is used with nouns to refer to a specific object or concept in the real world, for example "اشتريتُ السيارةً "اشتر"

Beside the definite article "the", definiteness is also represented by the following five ways:

1. Pronouns, for e.g.: انت ,هو

2. Demonstratives, for e.g.: هذا, هذه, هذ هذان

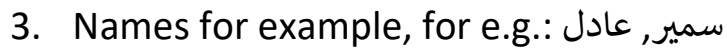

4. Relative pronouns, for e.g.: الذي, التي , الذين عادل:

5. Genitives: a noun is used with the previously mentioned, for e.g. سيارة ماهر, كتابي :لتين

Concerning the indefiniteness, the article " $n$ " "التنوين" can be attached to a noun to indicate an object which the hearer has no idea about it. For example:

I bought a house

اشتريتُ منزلاً.

The article "al" is used to denote things in general, not specific: الجاهل يؤكد و العالم يشك و العاقل يتروى. 


\section{QALAAI ZANISTSCIENTIFIC JOURNAL \\ A Scientific Quarterly Refereed Journal Issued by Lebanese French University - Erbil, Kurdistan, Iraq \\ Vol. (6), No (3), Summer 2021 \\ ISSN 2518-6566 (Online) - ISSN 2518-6558 (Print)}

The nouns " العالم, الجاهل,العاقل" indicate a general idea and generic reference.

Nouns can also be indefinite preceded by "al" and they refer to specific objects in reality like the ones that are unique, such as names of people, cities, moon, and earth and so on, as in the following verse cited from the Glorious Qur'an:

وَالشَّمْسنَ وَالْقَمَرَ رَاَِيَتْهُمْ لِي سَاجِدِينَ

The relationship between definiteness and individualization is not straightforward, simply, because the syntactic rules impact the definite marking. It can be said that the abstract and generic nouns are marked with the definite article "al", as well as the nouns that refer to unspecific entities or refer to any member of the class, while the human nouns may not take the definite article.

Khan (1984: 454) classifies certain features that can be provided to analyze nominals in spoken Arabic, lists and calls them classes of individuation. The individuated ones include:

1. Definite: القلم /the pen

2. Non-reflexive : كتب الطالب واجبه / The student completed his homework. The

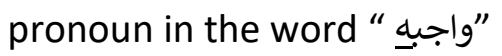

3. Specific, like people nouns : خالد / الدّالد / Khalid

4. Concrete: سيارة , السيارة / the car / a car

5. Qualified: الكتاب مفيد, the word/ The book is useful. "الكتابابل is the qualified noun.

6. Proper: المنزل/ the house

7. First, second, third human: انا، انت،هو / I, Your, He

And the non-individuated are:

1. Indefinite: ساعةٌ / a watch

2. Reflexive component: نفسه، نسفهم/themselves/himself

3. Generic: مدينة /حبِّ/ city

4. Abstract: /حبّ / إنة love

5. Common: طالب/ a student

6. Inanimate: شارعْ : 


\section{QALAAI ZANISTSCIENTIFIC JOURNAL \\ A Scientific Quarterly Refereed Journal Issued by Lebanese French University - Erbil, Kurdistan, Iraq \\ Vol. (6), No (3), Summer 2021 \\ ISSN 2518-6566 (Online) - ISSN 2518-6558 (Print)}

\section{Translation}

Translation can be defined as a process of replacing a text in one language with an equivalent text in another language. Since the chosen examples for analysis are literary texts, Svory's (1969) literary translation will be used.

\subsection{Savory Types of Translation}

Savory (1969) classifies translation into two types:

\subsubsection{Literary Translation}

This type of translation comprises the translation of all forms of writing in which the form is not less important than the content. This includes the translation of prose into-poetry, poetry into-prose.

\subsubsection{Non-Literary Translation}

It includes the translation of all scientific and technical material in which the content has priority over the form. The main concern is to reproduce the information of the original text with a high degree of accuracy.

\section{Data Analysis}

1) SLT Russian: «Какое чудо эти звезды, - сказал ей возлюбленный, - и как чудесна власть любви!» (Wilde, 2000:153)

TLT (1) English: "How wonderful the stars are", he said to her, "and how wonderful is the power of love!"

TLT (2) Arabic:

قال لها: كم النجوم رائعة وكم هي رائعة قوة الحب.

Table: (1)

\begin{tabular}{|c|c|c|c|c|c|}
\hline \multicolumn{2}{|c|}{ SL } & \multicolumn{3}{c|}{ TL } \\
\hline \multicolumn{2}{|c|}{ Russian } & \multicolumn{2}{c|}{ English } & \multicolumn{2}{c|}{ Arabic } \\
\hline Definiteness & Indefiniteness & Definiteness & Indefiniteness & Definiteness & Indefiniteness \\
\hline эти звезды & --- & the stars & --- & النجو & --- \\
\hline
\end{tabular}




\section{QALAAI ZANISTSCIENTIFIC JOURNAL}

A Scientific Quarterly Refereed Journal Issued by Lebanese French University - Erbil, Kurdistan, Iraq

Vol. (6), No (3), Summer 2021

ISSN 2518-6566 (Online) - ISSN 2518-6558 (Print)

2) SLT Russian: И он вынул из сундука тот плащ и ту янтарную цепь и показал этой женщине (Wilde, 2000:290)

TLT (1) English: And he took the cloak and the amber chain from the chest where they lay, and showed them to her.

TLT (2) Arabic:

$$
\text { و اخذ العباءة وطوق الكهرمان من الخزينة حيث يوضعون واراها لها. }
$$

Table: (2)

\begin{tabular}{|c|c|c|c|c|c|}
\hline \multicolumn{2}{|c|}{ SL } & \multicolumn{3}{c|}{ TL } & \multicolumn{2}{c|}{ Arabic } \\
\hline \multicolumn{2}{|c|}{ Russian } & \multicolumn{2}{c|}{ English } & --- \\
\hline Definiteness & Indefiniteness & Definiteness & Indefiniteness & Definiteness & Indefiniteness \\
\hline тот плащ & --- & the cloak & --- & العباءة &
\end{tabular}

3) SLT Russian: Не было ли у него на шее янтарной цепи? Не было ли на нем плаща из золотой парчи, расшитой звездами? (Wilde, 2000:291)

TLT (1) English: "Bare he not upon his neck a chain of amber? Was not round him a cloak of gold tissue embroidered with stars?"

TLT (2) Arabic:

الم يكن عنقه بدون طوق الكهرمان؟ الم يكن حوله عباءةً من النسيج الذهبي ومطرز بنجوم؟

Table: (3)

\begin{tabular}{|c|c|c|c|c|c|}
\hline \multicolumn{2}{|c|}{ SL } & \multicolumn{3}{|c|}{ TL } \\
\hline \multicolumn{2}{|c|}{ Russian } & \multicolumn{2}{|c|}{ English } & \multicolumn{2}{c|}{ Arabic } \\
\hline Definiteness & Indefiniteness & Definiteness & Indefiniteness & Definiteness & Indefiniteness \\
\hline--- & $\begin{array}{c}\text { янтарной } \\
\text { цепи }\end{array}$ & --- & a chain & طوق الكهرمان & --- \\
\hline
\end{tabular}

4) SLT Russian: Как-то ночью пролетала тем городом Ласточка. (Wilde, 2000:159)

TLT (1) English: One night there flew over the city a little Swallow. 


\section{QALAAI ZANISTSCIENTIFIC JOURNAL}

A Scientific Quarterly Refereed Journal Issued by Lebanese French University - Erbil, Kurdistan, Iraq

Vol. (6), No (3), Summer 2021

ISSN 2518-6566 (Online) - ISSN 2518-6558 (Print)

TLT (2) Arabic:

حلق طائر صغير في ليلةو ما فوق المدينة.

Table: (4)

\begin{tabular}{|c|c|c|c|c|c|}
\hline \multicolumn{2}{|c|}{ SL } & \multicolumn{3}{c|}{ TL } \\
\hline \multicolumn{2}{|c|}{ Russian } & \multicolumn{2}{c|}{ English } & \multicolumn{2}{c|}{ Arabic } \\
\hline Definiteness & Indefiniteness & Definiteness & Indefiniteness & Definiteness & Indefiniteness \\
\hline--- & Kaк-Tо HOчью & --- & one night & --- & dِ \\
\hline
\end{tabular}

5) SLT Russian: Жила давным-давно одна бедная вдова, и был у нее единственный сын Джек. (Wilde, 2000: 54)

TLT (1) English: Once upon a time there lived a poor widow who had an only son named Jack.

TLT (2) Arabic:

كان يا ما كان ارملةُّ فقيرةٌ لديها ولدّ وحيدُ اسمه جاك.

Table: (5)

\begin{tabular}{|c|c|c|c|c|c|}
\hline \multicolumn{2}{|c|}{ SL } & \multicolumn{3}{|c|}{ TL } \\
\hline \multicolumn{2}{|c|}{ Russian } & \multicolumn{2}{c|}{ English } & \multicolumn{2}{c|}{ Arabic } \\
\hline Definiteness & Indefiniteness & Definiteness & Indefiniteness & Definiteness & Indefiniteness \\
\hline--- & $\begin{array}{c}\text { давным- } \\
\text { давно }\end{array}$ & --- & once & ---- & ---- \\
\hline
\end{tabular}

6) SLT Russian: эта фотография была снята в последний день нашего рокового лета, всего за несколько минут до нашей второй и последней попытки обмануть судьбу. (Nabokov, 1991:32)

TLT (1) English: The photograph was taken on the last day of our fatal summer and just a few minutes before we made our second and final attempt to thwart fate.

TLT (2) Arabic:

التقطت الصورة في اليوم الاخير من صيفنا المصيري وبضعة دقائقوٍ قبل محاولتنا الاخيرة في مواجهة مصيرنا. 


\section{QALAAI ZANISTSCIENTIFIC JOURNAL}

A Scientific Quarterly Refereed Journal Issued by Lebanese French University - Erbil, Kurdistan, Iraq

Vol. (6), No (3), Summer 2021

ISSN 2518-6566 (Online) - ISSN 2518-6558 (Print)

Table: (6)

\begin{tabular}{|c|c|c|c|c|c|}
\hline \multirow{2}{*}{\multicolumn{2}{|c|}{$\frac{\text { SL }}{\text { Russian }}$}} & \multicolumn{4}{|c|}{$\mathrm{TL}$} \\
\hline & & & & & bic \\
\hline Definiteness & Indefiniteness & Definiteness & Indefiniteness & Definiteness & Indefiniteness \\
\hline $\begin{array}{c}\text { эта } \\
\text { фотография }\end{array}$ & --- & $\begin{array}{c}\text { the } \\
\text { photograph }\end{array}$ & --- & الصورة & ---- \\
\hline
\end{tabular}

7) SLT Russian: В театре ко мне обратилась одна девушка с просьбой поменяться местами. Эта девушка хотела сидеть рядом с подругой. (Sirota:2019)

TLT (1) English: In the theater, a girl approached me with a request to exchange places. The girl wanted to sit next to her friend.

TLT (2) Arabic:

اقتربت مني فتاةٌ في المسرح طالبة تبديل المقاعد. اذ ارادت الفتاة الجلوس بجانب صديقت

Table: (7)

\begin{tabular}{|c|c|c|c|c|c|}
\hline \multicolumn{2}{|c|}{ SL } & \multicolumn{3}{c|}{ TL } \\
\hline \multicolumn{2}{|c|}{ Russian } & \multicolumn{2}{c|}{ English } & \multicolumn{2}{c|}{ Arabic } \\
\hline Definiteness & Indefiniteness & Definiteness & Indefiniteness & Definiteness & Indefiniteness \\
\hline $\begin{array}{c}\text { одна } \\
\text { девушка }\end{array}$ & ----- & a girl & --- & --- \\
\hline
\end{tabular}

\subsection{Analysis \& Discussions}

Examples (1) and (2) demonstrate the case when in English the categorical meaning of certainty is expressed by the corresponding article, while in Russian this meaning is conveyed using these demonstrative pronouns "this, that, that". Thus, it should be noted that in this example in English the meaning of certainty is transmitted morphologically, and in Russian - lexically. In addition to the definite article in the example (2), one can notice that the meaning of certainty is conveyed by the possessive pronoun "her". In order to render this meaning into Russian, we applied a combination of a demonstrative pronoun "этой" / "this" and a noun "женщине" / woman during translation, thereby conveying the meaning of certainty lexically. As 


\section{QALAAI ZANISTSCIENTIFIC JOURNAL \\ A Scientific Quarterly Refereed Journal Issued by Lebanese French University - Erbil, Kurdistan, Iraq \\ Vol. (6), No (3), Summer 2021 \\ ISSN 2518-6566 (Online) - ISSN 2518-6558 (Print)}

for the Arabic rendering, definiteness in example (1) and (2) is represented by the definite article "نجو" and "نجوم" which precedes the noun".

The categorical meaning of uncertainty in (3) is expressed by the corresponding article in English, and is transmitted into Russian using a combination of nouns and adjectives in the genitive case. Regarding this example in Arabic, the indefiniteness is expressed by genitive, i.e., the noun "طوق" is followed by another noun preceded by "ال.

Sentence (4) is of great interest for analysis, because it clearly shows the categorical expression of uncertainty at the lexical-morphological and syntactic levels. The sentence begins with the numeral "one" that precedes the noun. In this case, "one" has a meaning of pronoun and expresses uncertainty, which finds the corresponding meaning in Russian equivalent, where the sentence begins with the adverb of time "как-то". The sentence uses the construction "there flew", which syntactically expresses the meaning of uncertainty. In this example, the categorical meaning of certainty in English translation is represented by the use of the definite article "the" before the noun "city", and in the Russian sentence this meaning is expressed lexically with the help of the demonstrative pronoun "тем" preceding the noun in the instrumental case. Suppose we consider the analyzed sentence of the Russian language from the point of view of the actual division of the sentence. In that case, we can notice that the new information is expressed using the indefinite article, the translation of the rheme is syntactically highlighted by setting the communicative center of the statement, in this case, the noun, at the end of the phrase. If in English translation, the transmission of new information (rheme) does not depend on its location in the sentence, due to the stable word order, in Russian, communicatively significant components that carry new information gravitate towards the end of the phrase. Thus, the uncertainty in the English sentence is expressed using the article a, and in Russian by putting a communicatively significant word at the end of the sentence. "One night" was translated into Arabic "ليلةٍ" the indefiniteness in this example is represented morphologically by the suffix " $-n$ " which is attached to the noun. 


\section{QALAAI ZANISTSCIENTIFIC JOURNAL \\ A Scientific Quarterly Refereed Journal Issued by Lebanese French University - Erbil, Kurdistan, Iraq \\ Vol. (6), No (3), Summer 2021 \\ ISSN 2518-6566 (Online) - ISSN 2518-6558 (Print)}

Analyzing the translation of sentence (5), it is seen that the use of the adverb of indefinite time "once upon a time", which is a characteristic of a fabulous text, introduces the reader into an indefinite space of time. This adverb expresses the categorical meaning of uncertainty, which in Russian is also transmitted by the adverb of indefinite time. The expression "a poor widow who had an only son" conveys the meaning of certainty, since we use the conjunctive pronoun "who", which creates a sentence with the category of definiteness. In Russian, this value is transmitted lexically, with the help of the numeral "one", which is the determinant of the noun "widow". "Once upon a time" was translated lexically into Arabic by saying "كان يا مكان". It is obvious from the rendering that there are no articles used to show definiteness or indefiniteness. So, it can be said that there is zero article $(\varnothing)$.

Considering Russian sentence (6) we can observe that the category of definiteness is expressed by the demonstrative pronoun "эта" which is placed before the noun "фотография". In English translation the definite article "the" indicates the use of a noun in a specifically-nominal sense that is to denote the existent object, which is in sight, especially allocated or known to interlocutors due to certain circumstances of the objects. The Arabic translation shows the definite article "ال" used before the noun "الصورة" which the subject in this passive voice sentence.

(7) In the first sentence, the numeral "одна' / "оnе" does not indicate the number of designated objects. However, the expression of the categorical meaning of indefiniteness. Thus, we can conclude that in this Russian sentence, the numeral "one" is equivalent to the indefinite article. Similarly, the demonstrative pronoun "эта" / "this" corresponds to a definite article. In its semantics, the numeral "one" is countable-pronoun: in addition to the quantitative meaning, it has the meaning of a pronoun "some, someone, somebody, anyone, etc.", thus expressing the meaning of indefiniteness. Regarding the Arabic version, "a girl" was rendered into "فتاة". The indefiniteness " $a$ " is represented by the suffix "- $n$ " in Arabic which is used to talk about an object for the first time. 


\section{QALAAI ZANISTSCIENTIFIC JOURNAL \\ A Scientific Quarterly Refereed Journal Issued by Lebanese French University - Erbil, Kurdistan, Iraq \\ Vol. (6), No (3), Summer 2021 \\ ISSN 2518-6566 (Online) - ISSN 2518-6558 (Print)}

\section{Conclusions}

Practical analysis of translating from Russian, English and Arabic showed that:

1. Definiteness and indefiniteness are language-universal and in very few cases, are language-specific.

2. In English, the category of definiteness and indefiniteness is more often expressed using the definite article "the".

3. In Russian, definiteness/indefiniteness is expressed by using demonstrative pronouns (this, some, someone, one, etc.), that is, more lexically, or by setting the communicative center (noun) of the statement at the end of the phrase.

4. As for Arabic, definiteness is expressed by the definite article "ll" and indefiniteness by using the suffix "-n.

\section{References}

Al-Sulaimaan, M. M. D. \& Ahmed, R. Kh Alsinjari, (2018). Problems of Translating Definite and Indefinite Articles from English into Arabic, International Journal of English Literature and Social Sciences, Vol-3, Issue-6, pp. 1077-1131. https://dx.doi.org/10.22161/ijels.3.6.25

Chafe, W. L. (1976). Givenness, Contrastiveness, Definiteness, Subjects, Topics, and Point of View, Charles Le (ed) Subject and Topic: New York: Academic Press, pp. 25-55.

Guzeeva, K. A., Zatsepina, E. I. (2009). Sbornik uprazhnenii po perevodu. Angliiskii yazyk (Collection of Translation Exercises. English), Saint Petersburg: Perspektiva.

Krushel'nitskaya, K. G., Popov, M. N. (2002). Sovety perevodchiku (Advices for Translator), 2e izd., dop., Moscow: Astrel', AST

Khan, G. (1984). Object Markers and Agreement Pronouns in Semitic Languages. Bulletin of School of Oriental and African Studies Vol. XLIX, pp. 439-453.

Крылов, С. (1983). Морфологические механизмы выражения категории детерминации в современном русском языке. Разработка и применение лингвистических процессоро, Новосибирск.

Lyons, C. (1999). Definiteness, Cambridge: Cambridge University Press.

Savory, T. (1968). The Art of Translation, Boston: The Writer, Inc.

Набоков, Владимир (1991). Лолита, М.: АНС-принт. (Nabokov, Vladimir (1991): Lolita, Moscow: ANS-print).

Сирота, Елена (2019). Способы репрезентации категории определенности / неопределенности в современном русском языке: [Retrieved from: https://zenodo.org/record/3568020/files/Sirota_categorii.PDF?download=1] 


\section{QALAAI ZANISTSCIENTIFIC JOURNAL}

A Scientific Quarterly Refereed Journal Issued by Lebanese French University - Erbil, Kurdistan, Iraq

Vol. (6), No (3), Summer 2021

ISSN 2518-6566 (Online) - ISSN 2518-6558 (Print)

Уайлд, О. (2000). Сказки на английском и русском языках, М.: Радуга (Wilde, О. (2000):

Skaki na angliyskom i na russkom yaikah, Moscow: Raduga)

Фурсенко, Д. (1970). Порядок слов как одно из средств выражения неопределенности / определенности имен существительных. Русский язык за рубежом. -. № 4. С.68-72.

Якубинский, Л. (1953). История древнерусского языка. - М.: Учпедгиз.

Реформацкий, А. (2000). Ведение в языковедение, М.: Просвещение.

Будур, Н. (2003). Английская литературная сказка XIX - XX вв, М.: Астрель: АСТ.

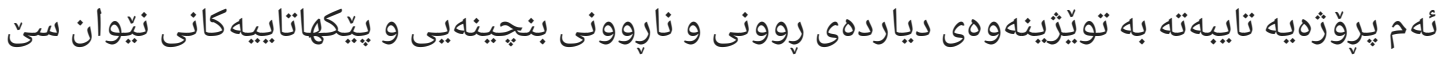

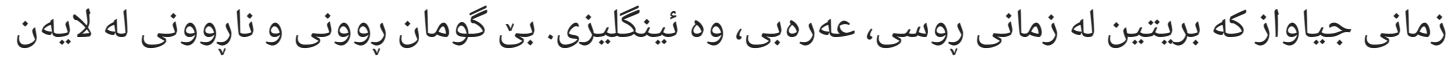

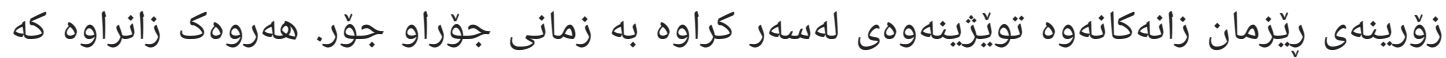

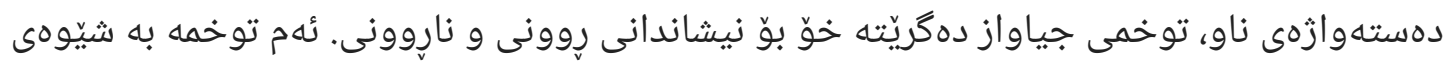

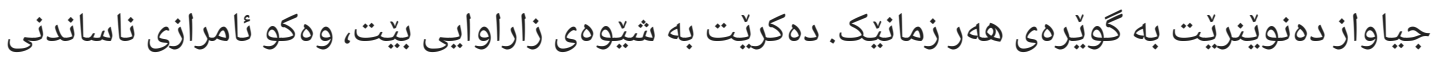
وه ئامرازى نهناسهى (the)

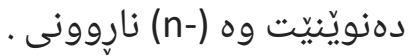
نامانجى ئهم تويَزينهوهيه:

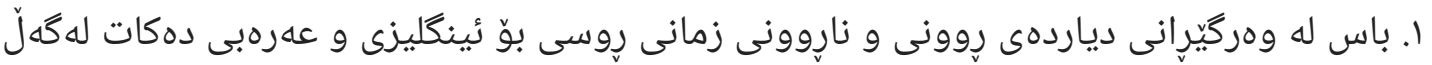

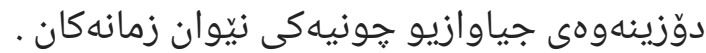

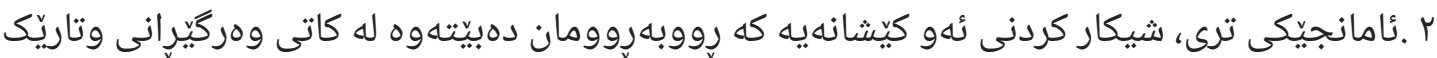

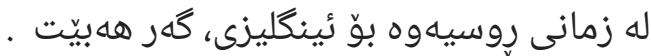

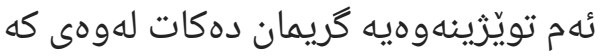

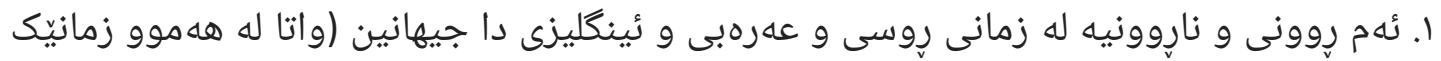

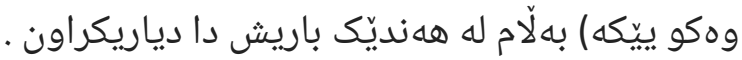

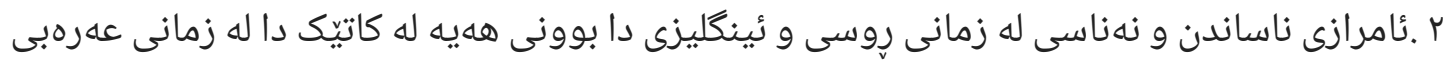

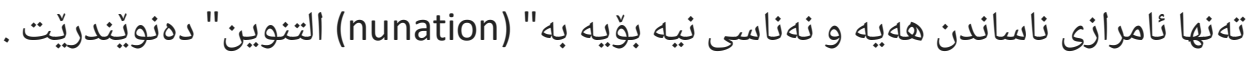
دوّزراوهى ئهم تويّزينهوهيه ئهوهمان نيشان دهدات كه ا. رِوونى و ناروونى جيهانيه. 


\section{QALAAI ZANISTSCIENTIFIC JOURNAL}

A Scientific Quarterly Refereed Journal Issued by Lebanese French University - Erbil, Kurdistan, Iraq

Vol. (6), No (3), Summer 2021

ISSN 2518-6566 (Online) - ISSN 2518-6558 (Print)

r. له زمانى ئينكليزى دا به شيّوهيهكى كشتى (the) بهكارديّت بوّ ئهم مهبهسته.

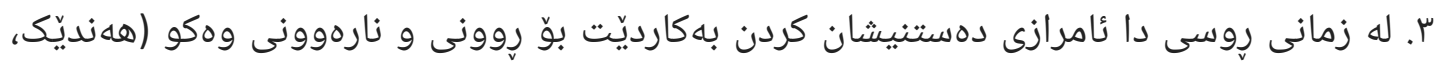

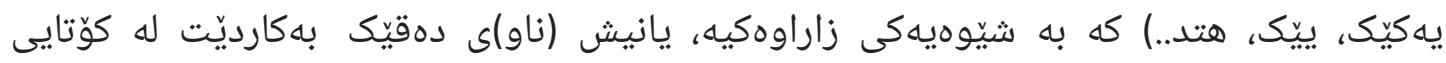
دهستهوازهييّك دا.

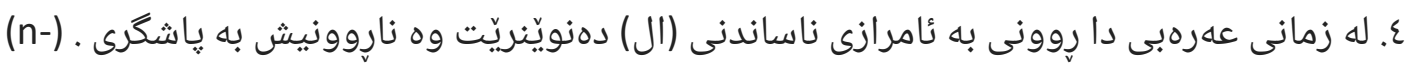

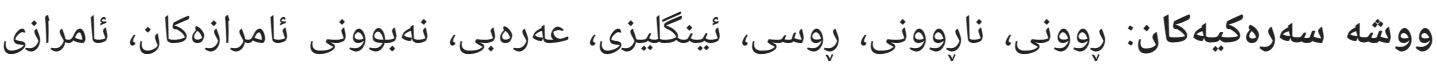

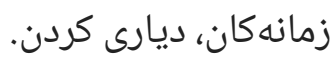

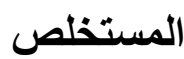

مشكلات ترجمة التعريف والتتكير من اللغة الروسية الى اللغة الانكليزية و العربية يهذف هذا البحث الى دراسة

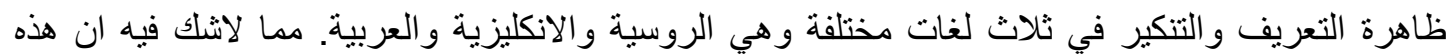

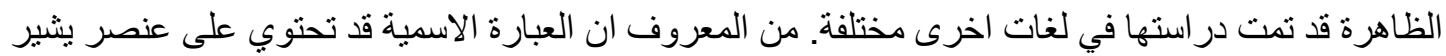

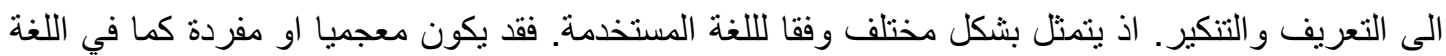

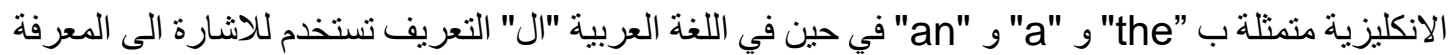

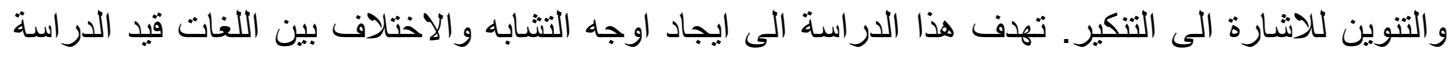

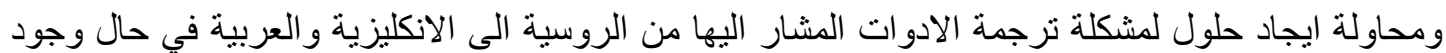

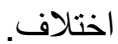

تتضمن الدر اسة الحالية الفرضيات التالية 1. ان ظاهرة التعريف والتتكير في اللغات الروسية والانكليزية و العربية هي ظاهرة عمومية اللغة وفي حالات قليلة هي خصوصة التية التية اللغة 2.

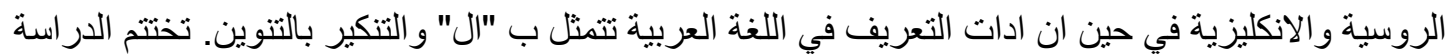

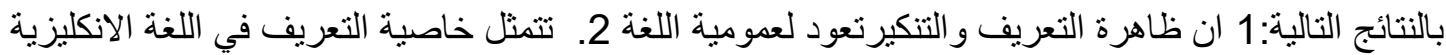

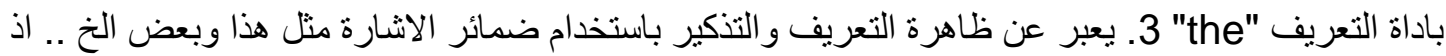

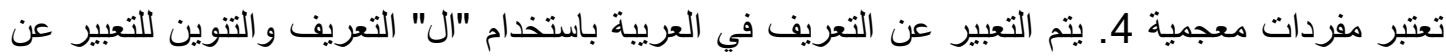

